\title{
Development of Integrated Social Science Education at SMPN 8 Martapura in Banjar District
}

\author{
Fitri Jamilah \\ SMP Negeri 8 Martapura \\ Banjar, Indonesia \\ fitrijmilah29@gmail.com
}

\author{
Dwi Atmono, Noor Amali \\ Economic Education Departement \\ Universitas Lambung Mangkurat \\ Banjarmasin, Indonesia \\ dwiatmono@ymail.com
}

\begin{abstract}
Integrated Social Science learning is essentially a learning approach that allows students either individually or in groups actively to search, explore, and find holistic and authentic concepts and principles. Thisresearch aims toexplore the learning process of Integrated Social Science, the barriers and obstacles in learning Integrated Social Science and development efforts in teaching Integrated Social Science SMP Negeri 8 Martapura. This method of this research was the Development Research (Research and Development) with Define and Designphases only that aim to develop Integrated Social Science at SMP Negeri 8 Martapura using a major potential-based model, problem-based model, and a topic-based model. The techniques of collecting data were interviews and documentation. The results showed that the Integrated Social Science Learning in SMPN 8 Martapura is still not been implemented, and the learning is still done separately. The main hindering factor is the limited ability of teachers in developing learning devices of Integrated Social Science subject. In this study, the researchers developed a learning device of Integrated Social Science. At the Define phase, analysis of standardcompetence and basic competencies was conducted and then all the standard and basic competencies were integrated through themes. The network ofstandard and basic competencies was made subsequently. In the Design phase, the syllabus and lesson plan were created for Integrated Social Science.
\end{abstract}

Keywords - Learning, Development, Integrated Social Science

\section{INTRODUCTION}

In essence, Social Science learning aims to develop the potential of learners in order to have a sensitivity to social problems that occur in community, have a positive attitude towards the improvement of all inequities that occur, and skillfully overcome problems especially in the region where they live. Social Science learning functions are in accordance with the educational dimension of Social Science, namely knowledge, attitudes, and social skills, which are needed to think critically in understanding local issues. Therefore, learners will be smart in dealing with various problems. Based on the context, utilizing the wisdom of existing local potential can be a good approach in supporting learners' achievement of competence in Social Science subject.
The Integrated learning model for Social Science is essentially a learning approach that enables students both individually and in groups to actively seek, explore, and find concepts and principles in a holistic and authentic way [1]. Social Science learning, or IPS (Indonesian acronym for Social Science) learning, in junior high school implemented with Integrated learning model is one of the curriculum implementation models that is recommended to be applied at all levels of education, ranging from elementary school (SD / MI) to high school (SMA / MA). Through integrated learning, students can gain hands-on experience, so they can intensively receive, store, and produce impressions about the things they learn. Thus, students are trained to be able to discover for themselves the various concepts studied holistically, meaningfully, authentically, and actively. The conceptual linkages they study and the relevant fields of study will form the scheme (concept) so that learners will gain wholeness and unanimity of knowledge. The acquisition of wholeness of learning, knowledge, and unanimity of views on life and the real world can only be reflected through integrated learning. The characteristic of IPS as a subject at the elementary and intermediate level is Integrated from a number of subjects in order that these subjects are more meaningful for learners. To achieve this goal, the organizing of learning materials is adapted to the environment, characteristics, and needs of students.

Social studies as a foundation in intellectual development, emotional, cultural, and social learners. Social studies can help student in solving social problems in society. This can be achieved if the application of science is done well [2].

IPS education is the disciplinary manifestation of various social sciences, which are based geography, economics, sociology, anthropology, state administration, and history. IPS education is not a subject with a single discipline but rather a multidisciplines, studies of several disciplines of the teaching dimensions [3].

Currently, schools in Banjar District, especially junior high schools, generally available IPS teachers consist of teachers of various disciplines, such as Geography, Sociology/Anthropology, Economics, and History. Teachers with such backgrounds certainly encounter difficulties to adapt into the integration of the social science disciplines. For example, teachers with Geography educational background 
lack optimal ability in economics and history, and vice versa. In addition, Integrated IPS learning also has consequences for reduced teaching hours of teachers covered by IPS, while the provisions relating to the obligations on the hours of teaching for each teacher remain. This causes Integrated IPS learning in junior high school and its development efforts are still experiencing many obstacles and barriers in bridging the achievement of mastery of a set of IPS competences by students.

At the beginning of the 2006 curriculum or $S B C$ curriculum, Integrated IPS learning is recommended for team teaching, so that IPS teachers do not have difficulties to teach together in every meeting, and teach according to the branch of IPS science they master. This makes it easier for teachers to teach IPS in an integrated way in junior high school. However, in line with the development of government policy with the provision of professional allowance or certification of teachers, team teaching is not possible to be implemented anymore. It is because the calculation of 4-hour lessons for $I P S$ in junior high school level per week can only be experienced by a teacher with an integrated computerized system through Sistem Data Pokok Pendidik (Dapodik), a system applied in Indonesia to count major teaching data of teachers.

In relation to the explanation, there needs to be study and innovation by IPS teachers on the development of integrated IPS learning so that the learning process of IPS in junior high schools in Banjar district, especially at SMP Negeri 8 Martapura, can take place effectively and efficiently in achieving the learning objectives

\section{METHOD}

The type of this study is Research Development (Research and Development) which aims to develop Integrated IPS learning in SMP Negeri 8 Martapura by using model based on the main potential, problem based model, and model based on topics. The procedures adopted in the development of education have two main objectives: (1) developing the product and (2) testing the effectiveness of the product. The first function is development, while the second function is validation. The Integrated IPS instructional development model used is Thiagarajan (Four-D) model, but only up to 2 stages, the definition and design stage, because the purpose of this research is only to develop Integrated IPS learning for class VII. The research was conducted at SMP Negeri 8 Martapura located at Taruna Praja Road Rt.05 Rw.06 Cindai Alus Village, Martapura Sub-district, Banjar District. this was chosen as the research location because the IPS teachers in the school have no educational background of IPS but geography and economic educations The main object of research is an integrated IPS learning for class VII.

\section{Result AND Discussion}

IPS learning at SMP Negeri 8 Martapura is still not integrated. It is a reality and raises the question of why IPS teachers there still do not implement Integrated IPS learning. The researchers tried to explore the causes or constraints faced by teachers to carry out IPS learning in an integrated manner.
The results of the interviews reveal some of the causes of IPS learning in SMP Negeri 8 Martapura which is still separated or not yet integrated. The main cause is because IPS teachers in SMP Negeri 8 Martapura have not been able to develop integrated learning devices for IPS subject.

Integrated IPS learning is done by first organizing or mapping the themes, considering the material to be integrated includes four disciplines namely History, Economics, Sociology, and Geography. Mapping the themes is an activity to obtain a comprehensive and whole picture of all Standard Competences, Basic Competencies and Indicators from various disciplines within the IPS combined in the chosen themes. Thematic learning is a learning approach that integrates teaching materials and learning experiences through the integration of themes. The themes become binding link between one disciplines of science with other disciplines.

In learning model teacher presents the lesson with theme and sub theme that are agreed and connected with interdisciplinary so that students get the view and the whole relationship about the activities of different subjects.

Once the themes are formed, teacher prepares the mapping of Basic Competences. Basic Competences of IPS are adjusted to the existing themes. If there is a Basic Competence that is difficult to integrate into predetermined themes, then the Basic Competence is taught separately the themes of integrated IPS learning that has been organized / mapped are then compiled in several lesson plans by paying attention to the order of ease of the material or linkage of Basic Competences. Subsequently, the map of the themes and the lesson plans are included in the semester program in accordance with the applicable school year. The next step taken by Integrated IPS teachers is to complete the lesson plans with literature/material/source in accordance with the Basic Competences to be taught.

Based on the analysis and elaboration of the results of the research, related to the development of Integrated IPS learning in SMP Negeri 8, several points are highlighted as follows:

\section{A. Stage I: Define}

The results of the front-end analysis underline that the main problem in Integrated IPS learning faced by Integrated IPS teachers at SMPN 8 Martapura is to integrate various disciplines into a theme of learning in order to achieve the basic competences of the subjects concerned. Based on the results of front-end analysis, it is found that the implementation of learning themes in Integrated IPS is done by first doing the theme mapping. From the mapping of these themes, there are many materials that can be associated with local potential and the surrounding. This is certainly in line with the vision, mission and objectives of the school which among others have a caring and cultured environment. Furthermore, there is only local potential and environmental culture which is suitable and can be used as teaching materials for further integration into theme learning in Integrated IPS lesson.

In the student analysis, the environmental background of students of SMPN 8 Martapura mostly is farming and fishery. 
Typical hardworking and high social awareness of the surroundings must be a manifestation of the character and competence of students which will assist in mastering the competence of the Integrated IPS relating to the internalization and integration of environmental themes.

After mapping the themes on the Integrated IPS learning, the teachers compile the concepts of the materials to be taught. By looking at existing concepts teachers can easily determine the source of materials, and what media are appropriate and which will be used to support IPS Integrated learning. For materials with certain concepts, environmental material and media, especially the environment around the school in accordance with the facts to be taught. Once the concepts are subsequently prepared, important pointers of the concepts are compiled to enrich the materials. Important pointers are arranged in connection with the integration of the environment into integrated IPS materials. Among others are the dangers of pollution in schools (water, air, and land contamination), saving of materials and school equipment (energy saving) in economic learning, hot weather in schools, and others.

The formulation of objectives is done by summarizing the results of various analyzes that have been done, looking at the problems, looking at potential of students, reviewing the concepts that have been compiled, and making task sequences, and finally the objectives are realistic to achieve.

\section{B. Stage II: Design}

The first is the preparation of (constructing criterionreferenced test). Preparing minimum passing criteria (KKM, Indonesian term), starting from KKM for basic competence, KKM for standard competence, which eventually become KKM for Integrated IPS per class. The preparation of KKM conducted at SMPN 8 Martapura is by giving score on each basic competence which includes: a). essential, meaning that basic competence is strongly necessary, less necessary, or not required to be taught to students, b). complexity, meaning that $\mathrm{KD}$ is categorized as very complex, complex, or simple, c). carrying capacity, meaning that KD is taught if the school has complete facilities, less complete, or even incomplete facilities to support the learning of the $\mathrm{KD}, \mathrm{d}$ ). student intake, meaning that $\mathrm{KD}$ is taught to students whether the students already have previous knowledge or not. The results of the KKM score is then summed and divided by the maximum score to obtain the desired KKM as a benchmark for learners to master competence taught and pass it. The media selection prioritizes on the most appropriate media and feasible both by teachers, easier to be understood by learners and owned by the school, or at least easily obtained. Media with environmental contexts are such as school cooperatives, school yard, etc. in addition to processed media such as maps, globes, and pictures are a top priority not only for integrated IPS but also other subjects. The use of media in IPS can improve the learning outcomes [5].

The format selection and the format of the lesson plan of Integrated IPS learning at SMPN 8 Martapura is arranged in the following sequence: subject identities, standard competence, basic competence, learning indicators, learning objectives, teaching materials, time allocation, learning methods, learning activities, learning assessment, and learning resources. The format allows teachers to construct ideas, and learning strategies to their preference, so that integrated IPS learning can be effective and efficient.

IPS Learning to be fun is to use constructivistic models. Evaluate the learning process is more important than the result. Evaluation of this process should be able noting the capabilities and skills developed inside teaching and learning activities [4].

Initial design of Integrated IPS learning is in the form of learning devices that will be used and required in learning including: course syllabus, lesson plan according to basic competence, subject journals, progress reports, assessment format, remedial format, and attendance of students. The availability of the minimal learning device can illustrate the readiness of teacher before beginning the teaching and learning process.

This research resulted in the development of Integrated IPS learning in accordance with the development of three models as follows:

\section{1) Integration Model based on Topics}

Integrated IPS learning development based on topic resulted in the mapping of Standard Competence and Basic Competences through themes such as Indonesiaku nan Indah, developed in the light of the various disciplines covered by IPS. Indonesiaku nan Indah in this case viewed from the diversity of facial forms of the earth in Indonesia is covered in the discipline of Geography. Sociologically, the beauty of Indonesia can also affect social interaction in society or vice versa. Historically from time to time Indonesia is always changing. The next is mastery of the concept of human beings as moral social and economic beings in meeting the needs.

\section{2) Integration Model based on Major Potential}

The integration of IPS can be developed through topics based on the major potential, for example, "Nenek Moyangku Seorang Pelaut". The theme of Indonesian marine potential ranges from natural factors, historical chronological arrival of the ancestors of Indonesia, to community behavior through social interaction in coastal areas, as well as economic activities in meeting the needs of life. Through the study of the major potentials that exist in the area, then students can understand the condition of the region as well as understand the Basic Competence found in some disciplines incorporated in the IPS.

\section{3) Integration Model Based on Problems}

The other integrated learning model in IPS is based on existing problems, which in this research is "Lapindo Mud". In integrated learning, Lapindo Mudflow is viewed from several social factors that influence it. Among these are geography, economic factors, social process factors as well as behavior of society against the rules / norms.

\section{CONCLUSION}

IPS Integrated learning process in SMP Negeri 8 Martapura is still not implemented by teachers, but the 
development of IPS learning has been done by integrating environmental values into learning materials in accordance with Adiwiyata school policies implemented in SMPN 8 Martapura. Constraint in Integrated IPS learning in SMP Negeri 8 Martapura based on interviews with teachers of subjects IPS is that teachers only have educational background from one of the sub subjects in Social Studies in junior high school consisting of Geography, History, Economics, and Sociology, so they find it difficult to develop integrated IPS learning. Integrated IPS learning will be easy to develop if teacher masters the material of the whole section so that it can integrate various disciplines into a theme of learning in order to achieve the basic competencies of the subjects concerned.

The Integrated IPS learning development model used is Thiagarajan (Four-D) model, but only up to 2 stages, namely the definition and design stage because the purpose of this research is only to develop the integrated IPS learning device. The development is done by first organizing or mapping the themes, considering that the material to be integrated includes four disciplines namely history, economics, sociology, and geography. Mapping the themes is an activity to obtain a comprehensive and whole picture of all Standard Competence, Basic Competences and Indicators from various disciplines within IPS, that are integrated into the chosen themes.
The development of Integrated IPS learning at SMP Negeri 8 Martapura needs to be done to improve the ability of IPS teachers in developing Integrated IPS learning, which is expected to help students to practice solving problems in everyday life by looking at the related aspects of either geographic nuances, history, economics, or sociology. The results of the development of Integrated IPS learning in this study are only from the stage of define and design. Therefore future researchers can continue this research until the next stages that are 'Develop' and 'Desseminate

\section{REFERENCES}

[1] Depdikbud, Kurikulum Pendidikan Dasar 1994, Jakarta: Departemen Pendidikan dan Kebudayaan, 1994

[2] E. Maryani dan H. Syamsudin, "Pengembangan Program Pembelajaran IPS untuk meningkatkan Kompetensi Keterampilan Sosial”, Jurnal Penelitian Vol. 9 No. 1, 2009

[3] M. Fadhli, "Pengembangan Media Pembelajaran Berbasis Video Kelas IV Sekolah Dasar", Jurnal Dimensi Pendidikan dan Pembelajaran Vol 3. No. 1, 2015

[4] F. Fahmi, "Pembelajaran IPS Terpadu yang Menyenangkan dengan Pendekatan Konstruktivisme", Nusantara, Jurnal Ilmu Pengetahuan Sosial , vol 1, 2016

[5] R. Afandi, "Pengembangan Media Pembelajaran Permainan Ular Tangga untuk Meningkatkan Motivasi Belajar Siswa dan Hasil Belajar IPS di Sekolah Dasar", JINoP Jurnal Inovasi Pembelajaran, Vol. 1, No 1, 2015, pp 77-89 